http://ejournal.upi.edu/index.php/jaz - e-mail: jurnal.zonasi@gmail.com dan jurnal_zonasi@upi.edu doi.org/10.17509/jaz.v3i3.28530

\title{
TEKNOLOGI BIOPORI PADA RUANG TERBUKA HIJAU Studi Kasus : Pulau Kodingareng Lompo, Kepulauan Sangkarrang, Makassar
}

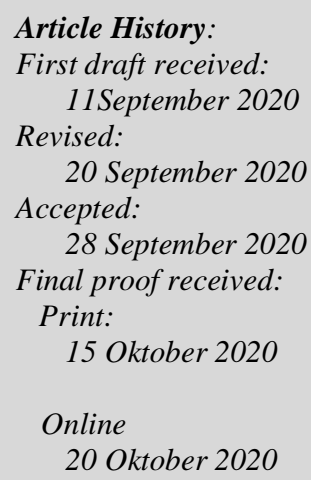

Jurnal Arsitektur ZONASI is indexed and listed in several databases:

SINTA 4 (Arjuna)

GARUDA (Garda Rujukan Digital)

Google Scholar

Dimensions

oneSearch

BASE

\section{Member: \\ Crossref \\ RJI \\ APTARI}

FJA (Forum Jurna Arsitektur) IAI AJPKM

\author{
Pratiwi Juniar Achmad Gani ${ }^{1}$ \\ Andi Muhammad Ikhsan ${ }^{2}$ \\ 1,2 Universitas Muslim Indonesia, Makassar 90231, Indonesia \\ Jalan Urip Sumoharjo Km. 5, Makassar \\ Email: pratiwijuniar.achmadgani@umi.ac.id \\ andimuhammad.ikhsan@umi.ac.id
}

\begin{abstract}
Kodingareng Lompo Island is an island which has a fairly dense population of approximately 4526 people and has a direct impact on the piles of waste that is generated every day, both in the form of organic and inorganic waste. The inhabitants of Kodingareng Lompo Island tend not to have the habit of handling waste by dumping it directly into the sea. The discarded waste causes bad odors and damages the marine ecosystem, so that waste handling with the $3 R$ concept (reduce, reuse, recycle) is part of a sustainable business that is made into compost and organic waste can be recycled into other more useful items, especially in open green space. This research was carried out in a non-experimental nature with a qualitative descriptive method based on the design or design which will be produced using a spatial approach by mapping the location as outlined in the description of the image and the biopore point placement scheme. The result shows that 28 biopore holes were needed to handle the organic impacts generated by residents and arranged in a grid pattern so that the water absorption flow was more natural.
\end{abstract}

Keywords: Organic trash, Green Open Space, Biopori Technology

Abstrak: Pulau Kodingareng Lompo adalah pulau yang memiliki jumlah penduduk yang cukup padat sekitar 4526 jiwa dan berdampak langsung terhadap timbulan sampah yang dihasilkan tiap harinya, baik berupa sampah organik maupun sampah unorganik. Penduduk pulau Kodingareng Lompo ini cenderung tidak memiliki kebiasaan penanganan sampah yang dilakukan dengan membuang langsung ke laut. Sampah yang dibuang, menjadi penyebab bau tidak sedap dan merusak ekosistem laut, sehingga penangan sampah dengan konsep 3R (reduce, reuse, recycle) sebagai bagian dari usaha berkelanjutan yang dijadikan kompos dan sampah organik dapat didaur ulang menjadi barang lain yang lebih bermanfaat utamanya di ruang terbuka hijau. Penelitian dilakukan bersifat non eksperimental dengan metode deskriptif kualitatif berdasarkan desain atau rancangan yang akan dihasilkan dengan metode pendekatan keruangan (spasial) dengan memetakan lokasi yang dituangkan dalam uraian gambar dan skema perletakan titik biopori. Hasil penelitian diperoleh bahwa diperlukan 28 lubang biopori untuk menangani timbulan saampak organik yang dihasilkan penduduk dan disusun dengan pola grid agar aliran penyerapan air lebih bersifat alamiah.

Kata Kunci: Sampah Organik; Ruang Terbuka Hijau; Teknologi Biopori.

\section{Pendahuluan}

Sampah adalah suatu bahan yang terbuang atau dibuang dari sumber hasil aktifitas manusia maupun alam yang belum memiliki nilai ekonomis. Bila sampah ini masuk ke dalam lingkungan (ke air, ke udara dan ke tanah) maka kualitas lingkungan akan menurun. Sampah yang dihasilkan oleh manusia yang akan semakin bertambah seiring dengan bertambah pula jumlah penduduk yang bermukim di suatu kawasan. 
(Arifin, 2012). Apabila pertambahan sampah tersebut tidak diolah dengan baik, maka sampah akan menjadi masalah serius. Masalah yang terjadi akibat adanya sampah cukup banyak, diantaranya berupa pencemaran lingkungan ataupun bencana alam seperti banjir dan longsor. Menurut Sayekti (2012 dalam Puspita, 2018) bahwa sampah merupakan masalah klasik yang dihadapi oleh negara-negara maju maupun berkembang dan hingga saat ini penanganan serta pengelolaan sampah masih terus dikembangkan, khususnya di Indonesia sebagai negara berkembang, permasalahan sampah menjadi masalah yang harus mendapat perhatian lebih seiring laju pertumbuhan penduduk yang terus meningkat. Tidak bisa kita pungkiri bahwa sampai saat ini masih banyak masyarakat yang berperilaku buruk terhadap lingkungan, Mereka membuang sampah sembarangan. Perilaku ini tidak mengenal tingkat pendidikan maupun status sosial masyarakat, di lingkungan kantor pemerintahan, fasilitas umum seperti bank, sekolah, puskesmas, taman kota, dan lain-lain.

Agar tidak terjadi pencemaran atau bencana maka sampah terutama sampah organik dapat diatasi langsung di sumbernya. Pemerintah telah mengatur dalam Undang-Undang Nomor 18 Tahun 2008 Tentang Pengelolaan Sampah dan Peraturan pemerintah Nomor 81 Tahun 2012 Tentang Pengelolaan Sampah Rumah Tangga Dan Sampah Sejenis Sampah Rumah Tangga dengan Pembatasan timbulan sampah (Reduce), pendauran ulang sampah (Recycle), dan pemanfaatan kembali sampah (Reuse) yang selanjutnya disebut pengelolaan sampah dengan prinsip 3R (Reduce, Reuse, Recycle) dimana ini merupakan pendekatan regulasi ramah lingkungan dari pemerintah sebagai usaha mengatasi sampah langsung di sumbernya. Menurut Ichsan \& Hulalata (2018;01) mengatakan bahwa resapan biopori merupakan teknologi tepat guna dan ramah lingkungan untuk mengatasi banjir yaitu dengan meningkatkan daya resap tanah pada air sehingga mengurangi limpasan permukaan dan genangan air yang timbul selama dan setelah hujan. Selanjutnya Juliandari (2013;2) bahwa usaha untuk meningkatkan kemampuan tanah dalam meresapkan air hujan adalah melalui teknologi pengendalian aliran permukaan dengan sistem biopori. Saluran dan lubang dalam sistem peresapan biopori digunakan sebagai simpanan dalam menampung dan meresapkan air tanah. Bertambahnya air yang meresap kedalam tanah dapat meningkatkan kuantitas air dalam tanah sehingga walaupun musim kemarau kebutuhan akan air sedikitnya dapat terpenuhi. Berkurangnya daerah resapan air hujan berimplikasi juga terhadap meningkatnya aliran permukaan yang dapat menimbulkan banjir pada waktu hujan lebat, berkurangnya potensi air tanah, dan pencemaran lingkungan menurut Kusmawati $(2012,10)$. Selanjutnya dengan melihat dari buruknya dampak banjir, maka sebagai manusia yang harus bertanggung jawab terhadap kelestarian bumi, kita harus berupaya untuk menanggulangi dan sebisa mungkin untuk mencegahnya. Oleh karena itu, harus diketahui penyebab banjir sehingga bisa diberikan solusi untuk mencegah dan menanggulanginya.Penyebab banjir tersebut antara lain akibat dari berkurangnya lahan terbuka yang berguna untuk resapan air, saluran-saluran pembuangan air serta sungai yang tidak lancar alirannya sehingga mengakibatkan luapan aliran sungai dan kurangnya kesadaran manusia untuk tidak membuang sampah ke aliran air (Karuniastuti, 2014).

Pulau kodingareng adalah salah satu pulau dalam gugusan kepulauan spermonde yang ada di Kota Makassar yang terdiri atas pulau Kodingareng Keke dan Kodingareng Lompo. Pulau Kodingareng Keke adalah pulau yang tidak berpenghuni, sementara pulau Kodingareng Lompo adalah pulau yang memiliki jumlah penduduk yang padat, yaitu berjumlah 4526 jiwa terdiri dari laki-laki 2276 jiwa dan perempuan 2250 jiwa yang terdiri atas $1081 \mathrm{KK}$ dengan luas wilayah daratan $14 \mathrm{Ha} .92 \%$ penduduk di pulau ini bekerja sebagai nelayan dan pedagang. Jika dibandingkan dengan pulau lain, Pulau kodingareng Lompo memiliki fasilitas yang cukup maju, terdapat instalasi listrik dengan generator dan panel tenaga surya yang beroperasi selama 24 jam. Jumlah penduduk yang cukup padat pada pulau Kodingareng Lompo ini selanjutnya berdampak langsung dengan banyaknya sampah yang dihasilkan tiap harinya, khususnya sampah organik dari lingkungan rumah tangga. Proses pemilahan terlebih dahulu juga telah dilakukan oleh penduduk setempat, dimana sampah organik dijadikan kompos dan sampah anorganik dikumpul untuk didaur ulang menjadi barang lain yang lebih bermanfaat. Namun dalam proses pembuatan kompos inilah dari sampah organik terkendala dengan lahan yang digunakan untuk mengolahnya dan menimbulkan bau yang tidak sedap terhadap penduduk setempat akibat proses composting tersebut dimana proses ini pula menyebabkan tumpukan sampah semakin berlebih. Sebagaimana dinyatakan oleh Meirinda dkk.(2018 dalam Samadikun, 2019) bahwa semakin banyaknya lahan terbangun dan kurangnya Ruang Terbuka Hijau (RTH) maka akan mengakibatkan berkurangnya kawasan resapan air bagi masyarakat. Berkurangnya zona peresapan air hujan menjadi salah satu penyebab menurunnya sumberdaya airtanah. Hal ini bila tidak dikelola dengan baik, akan menyebabkan terjadinya kelangkaan airtanah. Padahal, airtanah masih menjadi sumber utama dalam pemenuhan air bersih oleh masyarakat (Purwoarminta dkk., 2019 dalam Samadikun, 2019). Selain itu, ketiadaan daerah resapan air di pekarangan rumah akan memperbesar potensi terjadinya banjir di wilayah perkotaan (Elsie dkk., 2017). Dengan kondisi lahan penyerapan semakin sedikit, air hujan langsung mengalir ke saluran pembuangan dan eksploitasi air tanah semakin meningkat, 
maka diperlukan upaya pengembalian air tanah. Upaya yang dilakukan untuk mengendalikan kondisi ini antara lain dengan pembuatan biopori dan juga pengelolaan sampah organik melalui metode komposter. Studi yang sudah dilakukan menunjukkan bahwa jika lubang biopori diisi dengan sampah organik, maka permukaan resapan tidak akan tersumbat karena sampah organik akan membusuk dan meresap air (Widyastuti, 2013). Bahkan, metode pengisian lubang biopori dengan menggunakan sampah dapur (household waste) akan lebih cepat terurai dibanding pengisian dengan daun-daun kering saja (permanasari, 2018)

Berangkat dari permasalahan diatas, maka dilakukan penelitian mengenai pengembangan teknologi resapan biopori untuk mendapatkan berapa jumlah titik resapan biopori yang dibutuhkan serta bagaimana posisi sebaran resapan biopori agar dapat menanggulangi bau tidak sedap yang ada di pulau Kodingareng Lompo. Diharapkan hasil penelitian ini akan menjadi salah satu solusi dari penanggulangan sampah dan bau yang tidak sedap akibat proses composting sampah di Pulau Kodingareng Lompo.

\section{Metode Penelitian}

Penelitian ini menggunakan metode deskriptif-kualitatif dimana cara kerja metode ini dengan mendeskripsikan, menggambarkan, atau menyampaikannya secara rinci apa permasalahan yang terjadi di lapangan melalui bahasa tertulis (Atmadja, 2013 dalam Nuryanto 2020). Sedangankan pendekatan penelitain yang digunakan adalah pendekatan Post-Positivisme dimana memahami makna dan gambaran yang mendalam dari permasalahan yang terjadi di lokasi penelitian, dimana dalam hal ini lingkungan yang dimaksud adalah lingkungan permukiman masyarakat di pulau kodingareng lompo.

Karena penelitian ini bersifat naturalistik, maka data yang dikumpulkan berupa data deskriptif yang akan dituangkan dalam bentuk laporan ataupun uraian yang mengkombinasikan antara teknik pengumpulan data berupa 1) Observasi langsung ke lapangan, 2) Melakukan wawancara mendalam secara langsung kepada pemerintah maupun masyarakat setempat guna memperoleh data yang dibutuhkan dan yang berkaitan dengan penelitian ini dimana peneliti sendiri sebagai instrumen penelitian (Human Instrument). Peneliti adalah 'key instrumen' atau alat penelitian utama. Peneliti yang mengadakan sendiri pengamatan atau wawancara tak terstruktur, sering hanya menggunakan buku catatan, dan 3) Studi dokumentasi dengan mempelajari dokumen-dokumen dari berbagai laporan yang berhubungan dengan kegiatan penelitian ini.

Setelah data-data terkumpul, segera dituangkan dalam bentuk tulisan dan dianalisis melalui: 1)Reduksi data, yaitu data yang diperoleh pada objek amatan ditulis dalam bentuk uraian atau laporan terinci dan dianalisis terus menerus sejak memasuki lapangan. Laporan ini perlu direduksi, dirangkum, dipilih hal-hal yang pokok, difokuskan pada hal-hal yang penting sesuai dengan tujuan penelitian, dicari tema dan polanya. Jadi data dilapangan disusun lebih sistematis, ditonjolkan yang penting, diberi susunan yang jelas, sehingga lebih mudah dikendalikan kemudian 2) Display data, dimana data yang sudah dikumpulkan, agar dapat melihat gambaran keseluruhan atau bagian-bagian tertentu dari penelitian ini, akan dibuat berbagai macam sketsa ide gagasan. Dengan demikian peneliti dapat menguasai data dan tidak tenggelam dalam tumpukan detail. Membuat display ini merupakan bagian dari analisis. Jadi kedua macam kegiatan analisis di atas dilakukan selama penelitian pada pulau kodingareng lompo. Kedua langkah analisis ini saling berhubungan dan berlangsung terus menerus selama penelitian dilakukan. Jadi analisis pada penelitian ini berlangsung secara kontinyu dari awal hingga akhir penelitian.

\section{Hasil dan Pembahasan}

\subsection{Teknologi Biopori pada Ruang Terbuka Hijau di Pulau Kodingareng Lompo}

Sampah adalah suatu bahan yang terbuang atau dibuang dari sumber hasil aktifitas manusia maupun alam yang belum memiliki nilai ekonomis. Bila sampah ini masuk ke dalam lingkungan (ke air, ke udara dan ke tanah) maka kualitas lingkungan akan menurun (Colink, 1996 dalam Shobri, 2014). Pada pengelolaan sampah ramah lingkungan, prinsipnya adalah memilah sampah sebelum sampai ke tempat pembuangan akhir sampah (TPA) menjadi sampah organik, anorganik, dan sampah-sampah yang sudah sulit untuk di daur ulang, sehingga volume sampah yang diangkut dan dibuang ke TPA menjadi berkurang. Sampah organik dan anorganik hasil pemilahan tersebut selanjutnya dapat didaur ulang. 


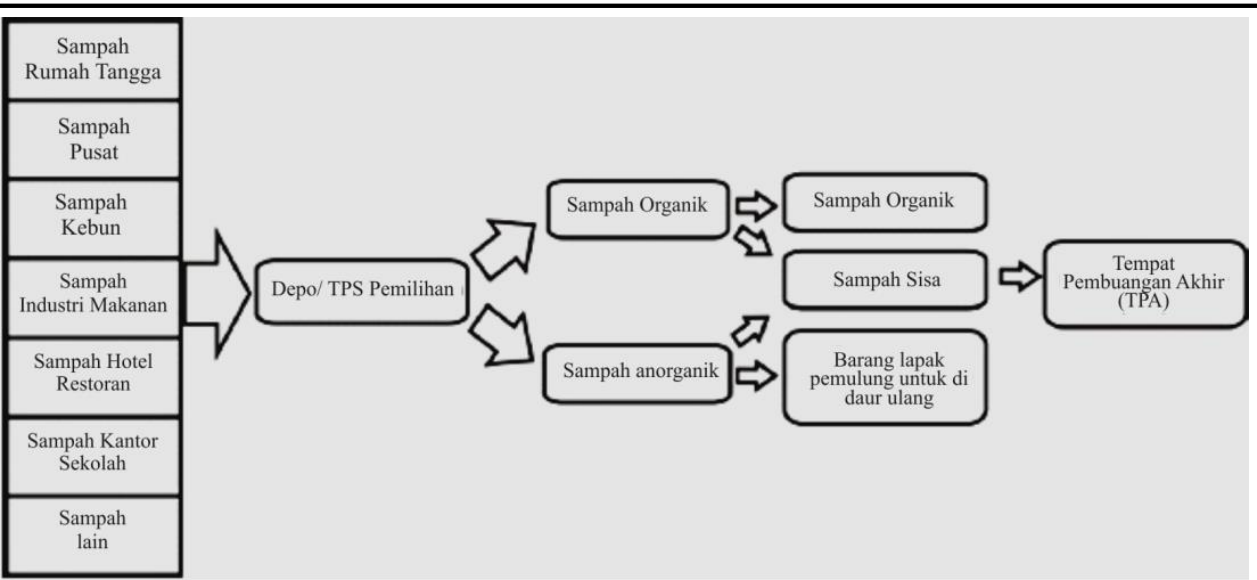

Gambar 1. Tahapan pengolahan sampah perkotaan

Colink, 1996; Shobri, 2014

Menurut Wiedarti $(2015,1)$ biopori adalah metode untuk mengatasi permasalahan daya serap air yang semakin menurun. Bentuk biopori menyerupai liang (terowongan kecil) di dalam tanah dan bercabang cabang dan sangat efektif untuk menyalurkan air dan udara ke dalam tanah. Liang pori terbentuk oleh adanya pertumbuhan dan perkembangan akar tanaman, serta aktivitas fauna tanah seperti cacing tanah, rayap dan semut di dalam tanah. Agar lubang biopori tetap berfungsi secara optimal maka harus rutin ditambah dengan bahan organik, sehingga di dalam lubang resapan biopori akan tetap berlangsung proses pengomposan secara aerobik oleh mikroorganisme tanah. Bahan organik yang digunakan dapat diperoleh dari berbagai sumber antara lain sampah dapur rumah tangga, potongan atau pangkasan tanaman, sisa produksi pertanian yang tidak dimanfaatkan dan sebagainya. Sampah organik merupakan sampah yang berasal dari barang yang mengandung bahan-bahan organik, seperti sisa -sisa sayuran, hewan, kertas, potongan - potongan kayu dari peralatan rumah tangga, potongan - potongan ranting, rumput (Suhaidi, 2005 dalam Wiedarti, 2015).

Dalam perkembangannya sampah yang dihasilkan oleh masyarakat di Pulau Kodingareng Lompo sebanyak $72 \%$ menghasilkan sampah organik dan sisanya menghasilkan sampah anorganik. Sampah organik inilah yang selanjutnya tidak dapat didaur ulang kembali oleh masyarakat sehingga menghasilkan penumpukan sampah di depan rumah masing-masing. Selanjunya sebanyak $51 \%$ masyarakatnya merubah sampah menjadi pupuk kompos yang kemudian menjadi masalah baru dengan menghasilkan bau yang tidak sedap terhadap lingkungan tempat tinggal masyarakat. Dengan demikian masih perlu dikembangkan lagi teknologi yang ramah lingkungan dengan memanfaatkan sampah yang dihasilkan masyarakat dan juga mendukungan peresapan air ke dalam tanah menjadi lebih tepat guna, dipelihara dengan biaya yang lebih ekonomis dan tentunya ramah lingkungan dengan menggunakan lubang resapan biopori.



Gambar 2. Kodisi Sampah Organik di Pulau Kodingareng Lompo Sumber : Survei, 2019

Ada 2 jenis biopori, yaitu biopori alam dan biopori buatan. Biopori alam, yaitu lubang-lubang kecil pada tanah yang terbentuk karena aktivitas organisme yang hidup dalam tanah seperti cacing, rayap atau pergerakan akar-akar tanaman yang dalam tanah. Lubang tersebut akan berisi udara dan menjadi jalur 
mengalirnya air. Sehingga air hujan tidak langsung masuk ke saluran pembuangan air, akan tetapi meresap ke dalam tanah melalui lubang tersebut. sehingga bisa menjadi air tanah. Akan tetapi karena lahan terbuka di bumi sudah sangat berkurang, maka biopori yang terbentuk secara alami pun semakin berkurang (Maryati, 2010).

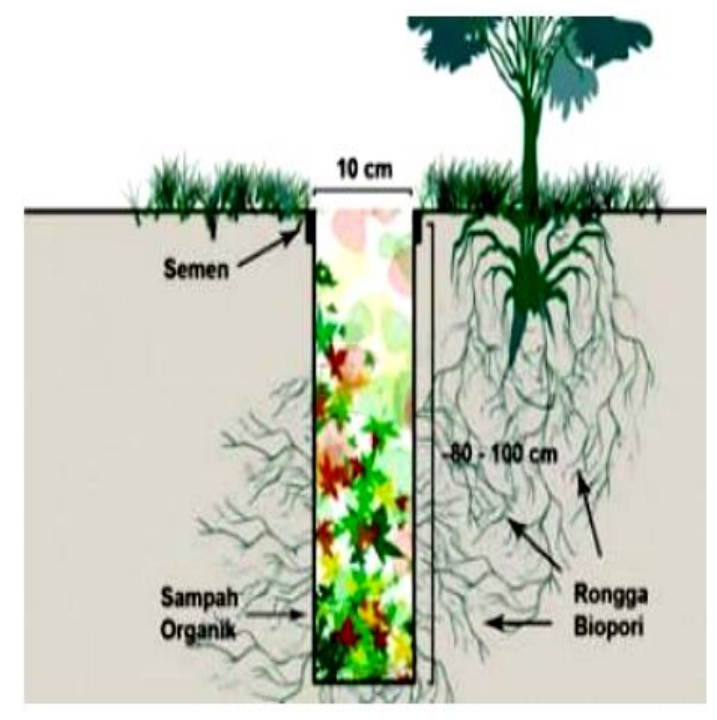

Gambar 3. Ilustrasi lubang biopori alamiah Colink, 1996; Shobri, 2014

Ide dari pembuatan biorpori buatan adalah mengadopsi teknologi biopori alami yang memiliki kawasan/ lahan sempit. Biopori buatan yang selanjutnya disebut lubang resapan biopori adalah lubang silindris yang dibuat secara vertikal ke dalam tanah dengan diameter 10-30 cm, kedalaman sekitar $100 \mathrm{~cm}$ atau tidak melebihi kedalaman muka air tanah. Lubang kemudian diisi dengan sampah organik yang berfungsi untuk menghidupkan mikroorganisme tanah, seperti cacing. Mikroorganisme atau fauna dalam tanah ini akan membentuk pori-pori atau terowongan dalam tanah (biopori) yang dapat mempercepat resapan air ke dalam tanah secara horizontal. Menurut Colink (1996) manfaat lubang resapan biopori (Shobri, 1994) adalah :

1. Meningkatkan daya resap air, adanya lubang resapan biopori tentu akan menambah bidang resapan air. Dengan adanya aktivitas organisme tanah maka biopori akan terbentuk, dan senantiasa terpelihara keberadaannya. Maka, dengan sendirinya area resapan ini akan terjaga kemampuannya dalam meresap air. Dengan begitu, seiring meningkatnya pembuatan lubang resapan biopori akan meningkatkan kemampuan dalam meresapkan air.

2. Mencegah banjir, banjir sendiri telah menjadi bencana yang merugikan bagi warga di berbagai wilayah di Indonesia, khususnya di kota-kota besar. Keberadaan lubang biopori dapat menjadi salah satu solusi dari masalah tersebut. Bila setiap rumah, kantor atau tiap bangunan memiliki biopori berarti jumlah air yang segera meresap ke tanah tentu lebih banyak dan dapat mencegah terjadinya banjir.

3. Meningkatkan kualitas air tanah, organisme atau fauna yang berperan dalam penguraian sampah di lubang biopori mampu membuat sampah menjadi mineral-mineral yang kemudian dapat larut dalam air. Oleh karena itu, air tanah menjadi berkualitas karena mengandung mineral.

4. Tempat pembuangan sampah organik, banyaknya sampah yang bertumpuk juga telah menjadi masalah tersendiri. Pemisahan sampah berdasarkan jenisnya yaitu organik dan anorganik dapat mengurangi permasalahan tumpukan sampah domestik itu. Untuk sampah anorganik dapat didaur ulang, sedangkan sampah organik dapat dibuang ke dalam lubang biopori tersebut.

5. Mengubah sampah organik menjadi kompos, cara kerja lubang resapan biopori ini adalah dengan adanya organisme tanah yang menguraikan sampah organik yang ditanam dalam lubang. Sampah menjadi sumber energi bagi organisme tersebut. Sampah yang diuraikan akan menjadi kompos. Sehingga tentu saja selain berfungsi sebagai area peresapan air, lubang biopori juga berfumngsi sebagai "produsen" kompos. Kompos tersebut dapat dipanen dan dimanfaatkan untuk pupuk organik. Pupuk organik ini tentu sangat bermanfaat untuk budi daya tanaman organik.

6. Memanfaatkan peran aktivitas fauna tanah dan akar tanaman, dengan adanya lubang resapan biopori, maka fauna tanah tentu akan beraktivitas dengan menciptakan rongga-rongga di dalam tanah yang 
nantinya menjadi saluran air untuk meresap ke dalam tanah. Peranan fauna dan akar-akar tanaman akan terus menjaga terbentuknya ronggarongga dalam tanah, tanpa adanya campur tangan manusia. Proses alamiah tersebut tentu akan menghemat biaya dan tenaga. Dalam hal ini, peran manusia adalah terus memberikan pakan untuk fauna tanah itu dengan sampah organik secara berkala.

7. Mengatasi masalah yang ditimbulkan oleh genangan air, berfungsinya lubang resapan biopori tentu akan mengurangi genangan air, sehingga berbagai macam penyakit akibat genangan air atau banjir seperti penyakit demam berdarah dan malaria dapat dihindari.

8. Membantu mencegah terjadinya pemanasan global, sampah tersebut akan terurai menjadi humus, sehingga tidak cepat diemisikan ke atmosfer sebagai gas rumah kaca.

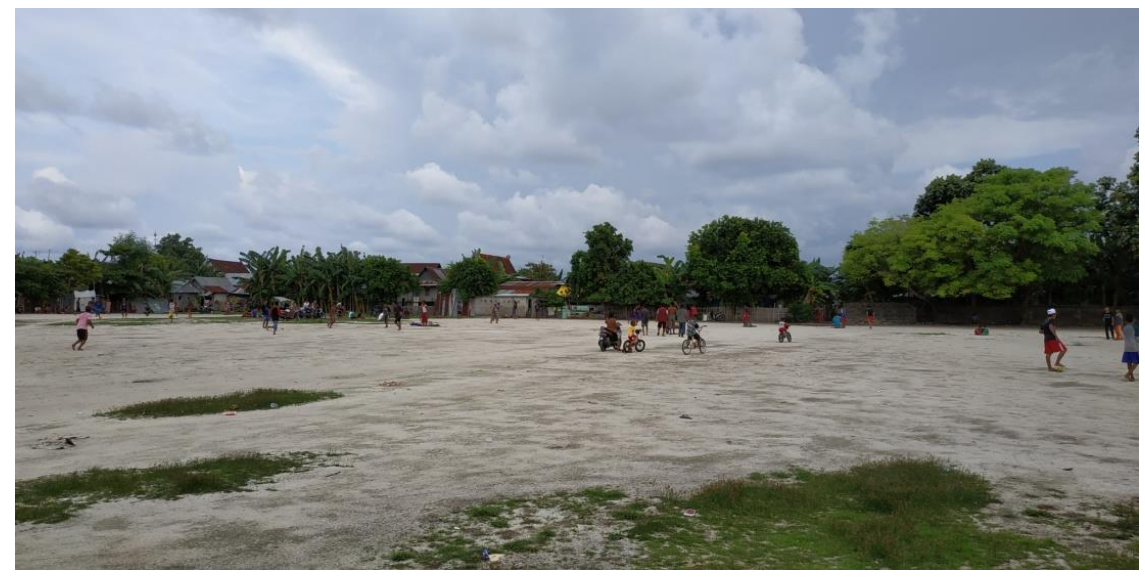

Gambar 4. Kondisi Ruang Terbuka Hijau di Pulau Kodingareng Lompo Sumber : Survei, 2019

\subsection{Kebutuhan Lubang Resapan Biopori pada Ruang Terbuka Hijau di Pulau Kodingareng Lompo}

Pembuatan lubang biopori merupakan solusi teknologi ramah lingkungan untuk mengatasi ketersediaan air tanah dengan memanfaatkan sampah organik melalui lubang kecil dalam tanah. Air dan sampah adalah dua hal yang tidak akan lepas dari kehidupan makhluk hidup, termasuk manusia. Setiap manusia setiap hari menghasilkan sampah dari aktifitas hidupnya. Terkadang sampah menjadi sumber masalah pencemaran lingkungan, padahal sampah mempunyai potensi besar dalam menyelamatkan lingkungan, jika diperlakukan secara arif dan bijaksana. Sementara air, sangat penting bagi makhluk hidup. Tanpa air, makhluk hidup akan mati. oleh karena itu, perlu dilakukan pengolahan air dan sampah untuk melangsungkan kehidupan.

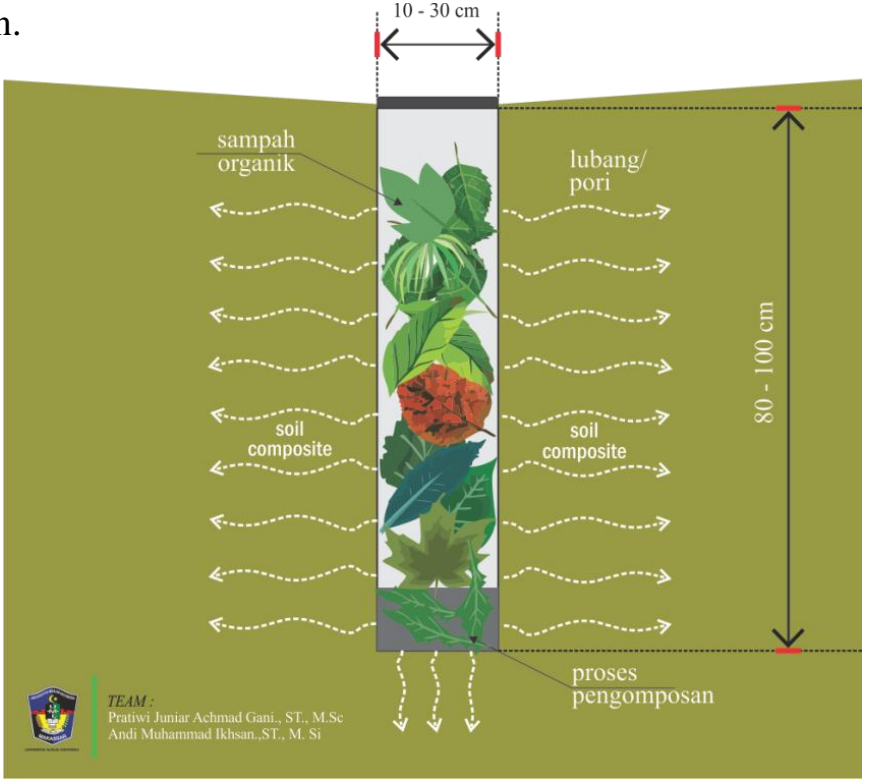

Gambar 5. Penampang Lubang Resapan Biopori

Sumber : Analisis Penulis, 2019 
Pembuatan biopori dapat dilakukan dimana saja, dengan ketersediaan tanah yang tidak terlalu luas. Dengan memanfaatkan lubang kecil dan sampah organik maka wilayah pulau kodingareng yang terlihat kering dan gersang akan berubah menjadi wilayah yang ramah lingkungan. Disamping itu, sampah organik yang tersimpan didalam lubang, dapat dijadikan sebagai sumber penghasil kompos yang dapat digunakan untuk menyuburkan tanaman. Pada penelitian ini lokasi penempatan Lubang Resapan Biopori berada di Ruang Terbuka Hijau

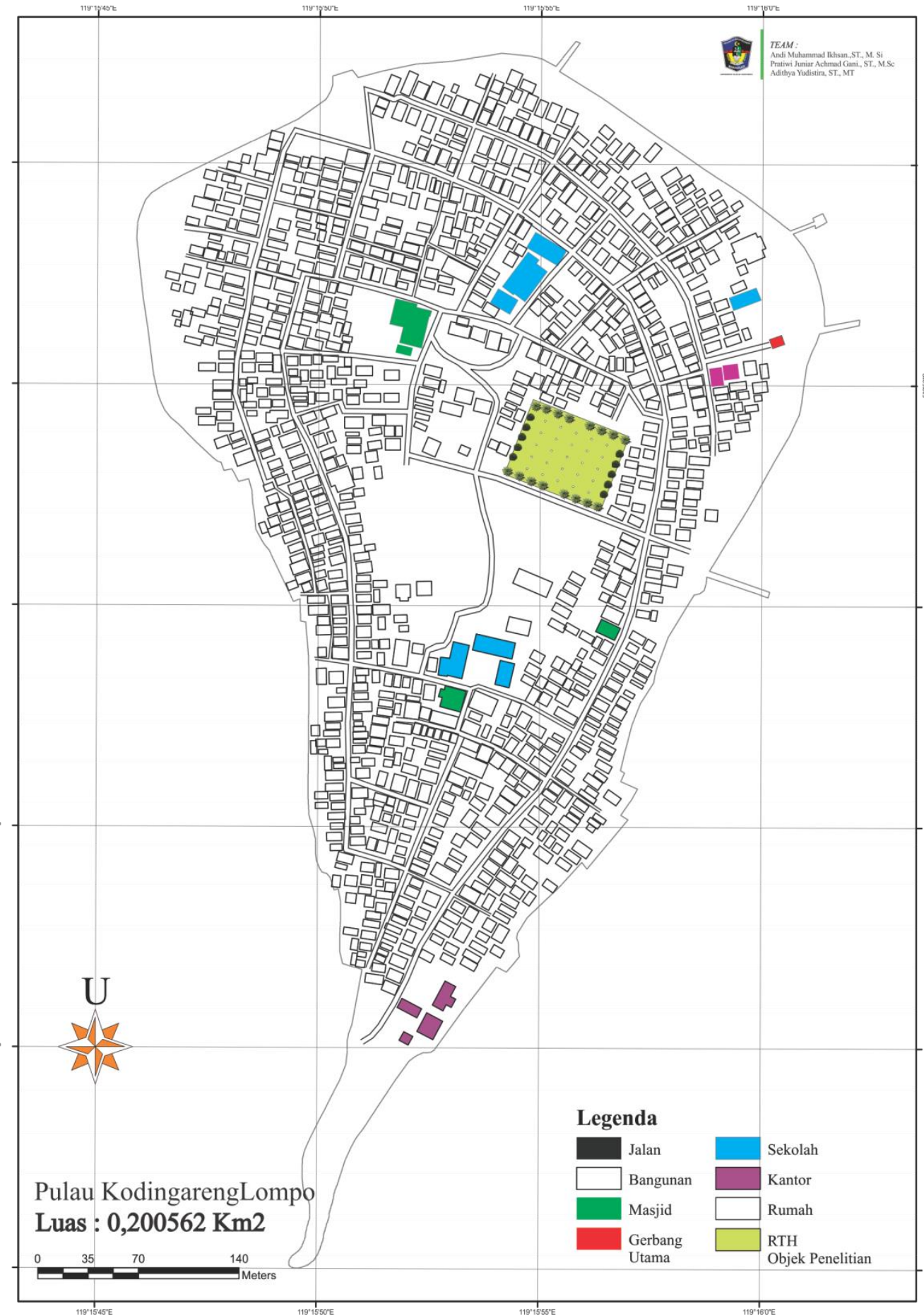

Gambar 6. Peta Sebaran Lubang Resapan Biopori pada Ruang Terbuka Hijau di Pulau Kodingareng Lompo

Sumber: analisis, 2019

Banyaknya lubang yang perlu dibuat dapat dihitung menggunakan persamaan : Jumlah Lubang Resapan Biopori = intensitas hujan Pulau Kodingareng Lompo yaitu 50 $\mathrm{mm} / \mathrm{jam}$ (hujan lebat), dengan laju peresapan air perlubang 3 liter/menit (180L/jam) pada luasan Ruang Terbuka Hijau sebesar 100m2 bidang kedap, perlu dibuat sebanyak: (50 x 
100) : 180 = 28 lubang resapan biopori. Bila lubang yang dibuat berdiameter $10 \mathrm{~cm}$ kedalaman $100 \mathrm{~cm}$, setiap lubang dapat menampung 7,8 Liter sampah organik, sehingga tiap lubang dapat diisi sampah organik 2-3 hari sampai penuh. Dengan demikian 28 lubang baru dapat dipenuhi sampah organik yang dihasilkan selama 56-84 hari. Hasil dari sampah organik di dalam lubang biopori berupa kompos yang dapat dipanen setelah 2-3 bulan pada saat musim kemarau, untuk selanjutnya dapat diisi kembali dengan sampah organik.

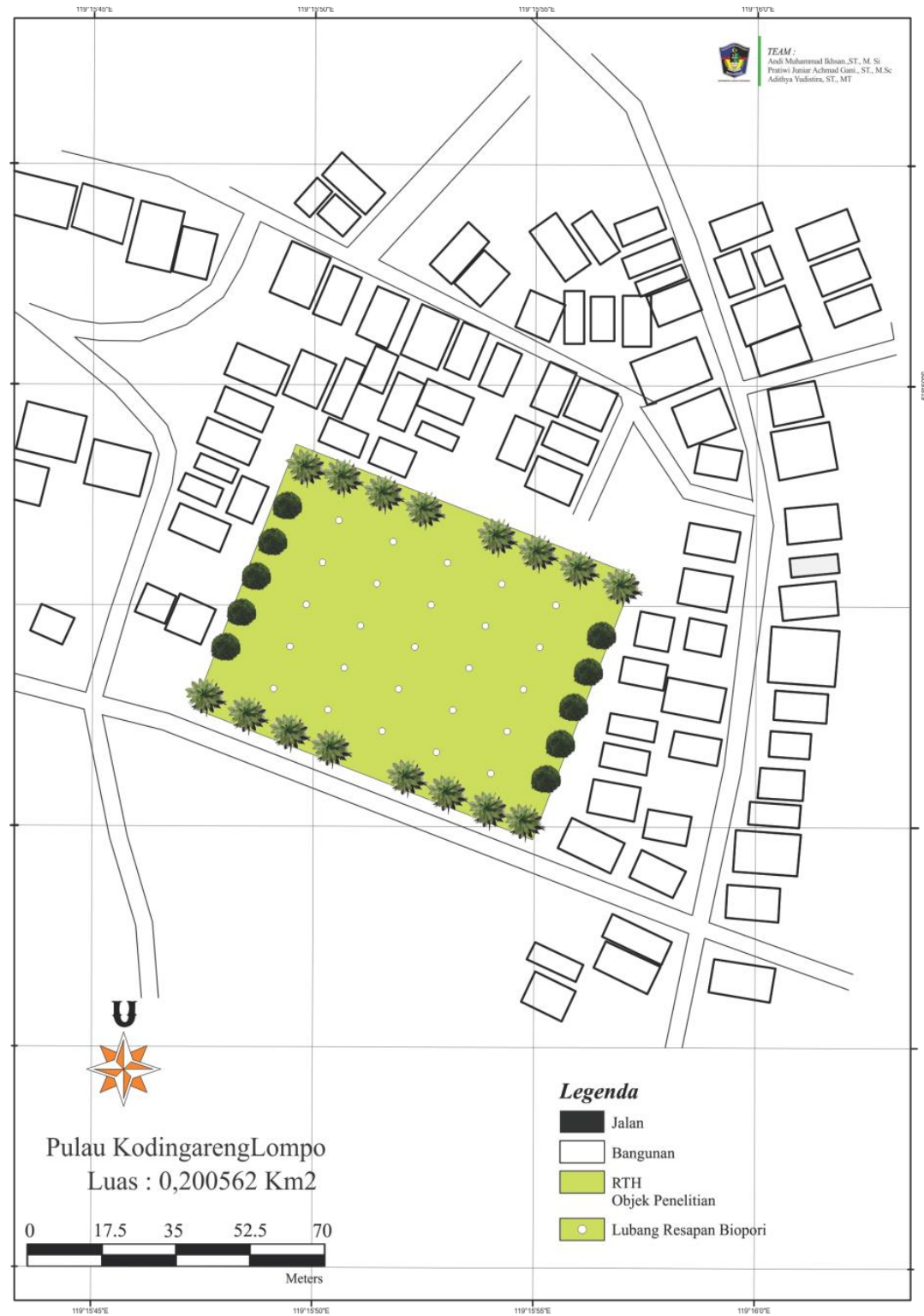

Gambar 7. Detail Sebaran Lubang Resapan Biopori pada Ruang Terbuka Hijau di Pulau Kodingareng Lompo

Sumber: analisis, 2019

Penyebaran lubang resapan biopori dilakukan dengan menggunakan pola grid mengingat Ruang terbuka Hijau yang ada di Pulau Kodingareng Lompo berbentuk persegi sehingga akan memudahkan dalam peresapan air yang ada di masing-masing lubang. Agar biopori yang telah kita buat bisa bertahan lama, maka ada beberapa yang harus anda lakukan untuk memelihara kondisi biopori, diantaranya adalah:

1. Lubang Resapan Biopori harus selalu terisi sampah organik

2. Sampah organik dapur bisa diambil sebagai kompos setelah dua minggu, sementara sampah kebun setelah dua bulan. Lama pembuatan kompos juga tergantung jenis tanah tempat pembuatan LRB, tanah lempung agak lebih lama proses kehancurannya. Pengambilan dilakukan dengan alat bor LRB.

3. Bila tidak diambil maka kompos akan terserap oleh tanah, LRB harus tetap dipantau supaya terisi sampah organik 


\section{Kesimpulan}

Penelitian ini pada akhirnya menghasilkan temuan penting dalam mengatasi permasalahan sampah dan bau tidak sedap yang terjadi di Pulau Kodingareng Lompo. Dalam penelitian ini ditemukan bahwa untuk diperlukan 28 lubang resapan biopori yang akan ditanam pada Ruang Terbuka Hijau di Pulau Kodingareng Lompo dengan kedalaman lubang $100 \mathrm{~cm}$ yang akan dapat menambung 7,8 liter sampah organik yang dihasilkan oleh masyarakat setempat. Untuk selanjutnya penyebaran lubang resapan biopori ini dapat dikembangkan lagi tidak hanya dilakukan di ruang terbuka hijau tetapi juga dapat mengikuti jaringan jalan yang ada di Pulau Kodingareng Lompo sebagai bagian integrasi laju jaringan penyerapan air secara alamiah, sehingga pemanfaatan pengurangan timbulan sampah organik dapat lebih maksimal.

\section{Ucapan Terima Kasih}

Ucapan terimakasih dihaturkan kepada Yayasan Badan Wakaf Universitas Muslim Indonesia , Lembaga Penelitian dan Pengembangan Sumberdaya Universitas Muslim Indonesia, Kelurang Kodingareng dan masyarakat setempat atas bantuan materil maupun immateril sehingga penelitian ini dapat terlaksana dan mengahasilkan pengembangan lubang resapan biopori pada Ruang Terbuka Hijau di Pulau Kodingareng Lompo.

\section{Referensi}

Arifin S, 2012. Menjaga Kelestarian Lingkungan Dengan Biopori. Jakarta: Prosiding The 4th International Conference on Indonesian Studies : "Unity, Diversity and Future".

Elsie, Harahap, I., Herlina N., Badrun, Y., Gesriantuti, N., 2017. Pembuatan Lubang Resapan Biopori Sebagai Alternatif Penanggulangan Banjir Di Kelurahan Maharatu Kecamatan Marpoyan Damai Pekanbaru. Jurnal Pengabdian Untuk Mu negeri (UMRI), 1(2), 93-97. doi: https://doi.org/10.37859/jpumri.v1i2.242

Juliandari, Murti ; Nirmala, Azwa ; Yuniarti, Erni. 2013. Efektivitas Lubang Resapan Biopori Terhadap Laju Resapan (Infiltrasi). Jurnal Teknologi Lingkungan Basah Universitas Tanjung Pura 1(1), 1 - 10. doi: http://dx.doi.org/10.26418/jtllb.v1i1.3441

Karuniastuti, Nurhenu. 2014. Teknologi Biopori Untuk Mengurangi Banjir Dan Tumpukan Sampah Organik. Jurnal Swara Patra Majalah Ilmiah Pusdiklat Migas 4 (2), 60 - 68.

Kusmawati, Tatiek ; Kusmiyarti, Tati Budi ; Gunasih, M.Tri ; Bhayunagiri, I.B.P ; Susila, K. Dharma ; Sutari, N. W. Sri. 2012. Penerapan Inovasi Teknologi Lubang Resapan Biopori Untuk Menjaga Ekosistem Tanah Daerah Rawan Banjir Di Banjar Wirasatya, Denpasar Selatan. Jurnal Udayana Mengabdi 11(1), 10 - 14 doi: https://doi.org/10.24843/BUM.2018.v17.i04.

Maryati, et al.. 2010. Lubang Resapan Biopori (LRB) teknologi Teknologi Tepat Guna Untuk Mengatasi Banjir Dan Sampah Serta Menjaga Kelestarian Air Bawah. Yogyakarta : Tim PPM Biopori UNY.

Nuryanto. 2020. Sosial-Ritual Dan Simbolik-Mistik Pada Pawon (Studi Kasus: Arsitektur Kasepuhan Ciptagelar-Sukabumi). Jurnal Arsitektur Zonasi 3(2), $125-135$. doi : doi.org/10.17509/jaz.v3i2.24962.

Permanasari, Eka ; Hendola, Feby ; Sahid ; Purisari, Rahma ; Safitri, Rahma. Penyelamatan Air Tanah dan Penanggulangan Sampah Melalui Program Biopori dan Komposter di Pemukiman Kecil Kelurahan Ciputat dan Ciputat Timur . Jurnal Pengabdian kepada Masyarakat - Indonesian Journal of Community Engagement 4(1), 51 - 64. doi: http://doi.org/10.22146/jpkm.33412

Puspita, Dewi; Sudirman; Budiman. 2018. Efektivitas Lubang Resapan Biopori Sebagai Penguraian Sampah Organik Dan Mencegah Genangan Air Di Rumah Sakit Madani. Jurnal Kolaborasi Sains 1(10), 87 93. doi : 10.31934/jom.v1i1.340

Samadikun, Budi Prasetyo. 2019. Penerapan Biopori untuk Meningkatkan Peresapan Air Hujan di Kawasan Perumahan. Jurnal Presipitasi : Media Pengembangan dan Pengembangan Teknik Lingkungan 16(3), 126 - 132. doi: https://doi.org/10.14710/presipitasi.v16i3.126-132

Shobri, Ahwan. 2014. Program Pilah Sampah Plastik, Kardus, Kertas Dalam Meningkatkan Nilai Kebersihan Siswa Dan Pendapatan Sekolah Di SDN Tambakaji 04, SDN Ngaliyan 01 Dan SDN Ngaliyan 03. IAIN Walisongo : http://eprints.walisongo.ac.id/3890/ 
Widyastuti, S. (2013). Perbandingan Jenis Sampah terhadap Lama Waktu Pengomposan Dalam Lubang Resapan Biopori. Jurnal Teknik Waktu UNIPA 11 (1), 5 - 14.

Wiedarti, Sri ; Lubis, M. Akhmar Yusfi ; Kumala, Oom. 2015. Aktifitas Degradasi Sampah Organik Dalam Biopori. Jurnal Ekologia:Jurnal Ilmiah Ilmu Dasar Dan Lingkungan Hidup 15(1), 1 - 5.

doi: 10.33751/ekol.v15i1.204 